WIDER Working Paper 2017/60

\title{
Fiscal capacity and social protection expenditure in developing nations
}

Syed Mansoob Murshed, ${ }^{1}$ Muhammad Badiuzzaman, ${ }^{2}$ and Mohammad Habibullah Pulok ${ }^{3}$

March 2017 
Abstract: There is scant analysis on the causal relationship between fiscal capacity and social protection expenditure in the developing world. We investigate the causal relationship between fiscal capacity of the state and social protection expenditure, hypothesizing that fiscal capacity is necessary but not sufficient for resource allocation in this area. Using a panel data instrumental variable approach, we find that greater fiscal capacity robustly raises social protection spending in developing countries between 1990 and 2010, providing strong evidence for social sector spending being augmented by enhanced fiscal capacity in the presence of a well-functioning democracy.

Keywords: fiscal capacity, inequality, institutions, social protection expenditure JEL classification: H51, H55, H62, O11

Acknowledgements: We are grateful to participants at the UNU-WIDER symposium on Political Economy of Social Protection in Developing Countries held in Mexico City, 8-10 February 2016, the UK DSA conference at Oxford, 12-14 September 2016, but especially Miguel Niño-Zarazúa for detailed comments that have improved the paper.

\footnotetext{
1 International Institute of Social Studies (ISS), Erasmus University Rotterdam, The Hague, The Netherlands and Coventry University, UK, corresponding author: murshed@iss.nl; 2 ISS, Erasmus University Rotterdam, The Hague, The Netherlands, badiuzzaman@iss.com; 3 CHERE, UTS Business School, University of Technology, Sydney (UTS), Australia, mohammad.pulok@chere.uts.edu.au.
}

This study has been prepared within the UNU-WIDER project on 'The political economy of social protection systems', which is part of a larger research project on 'The economics and politics of taxation and social protection'.

Copyright (C) UNU-WIDER 2017

Information and requests: publications@wider.unu.edu

ISSN 1798-7237 ISBN 978-92-9256-284-7

Typescript prepared by Sophie Richmond.

The United Nations University World Institute for Development Economics Research provides economic analysis and policy advice with the aim of promoting sustainable and equitable development. The Institute began operations in 1985 in Helsinki, Finland, as the first research and training centre of the United Nations University. Today it is a unique blend of think tank, research institute, and UN agency — providing a range of services from policy advice to governments as well as freely available original research.

The Institute is funded through income from an endowment fund with additional contributions to its work programme from Denmark, Finland, Sweden, and the United Kingdom.

Katajanokanlaituri 6 B, 00160 Helsinki, Finland

The views expressed in this paper are those of the author(s), and do not necessarily reflect the views of the Institute or the United Nations University, nor the programme/project donors. 
The positive impact of social protection programmes in areas such as poverty-inequality reduction, consumption smoothing, human development, and economic growth across various countries or regions of the world has been emphasized in the literature (Alderman and Yemtsov, 2012, 2013; Barrientos, 2013; Easterly, 2007; Gebregziabher and Niño-Zarazúa, 2014). There is evidence to suggest that social protection expenditure is on the rise in the developing world. Its implementation in developing countries is constrained by inadequate fiscal capacity. Among other factors, strengthening fiscal capacity has been identified as a crucial avenue for financing social protection schemes (ILO 2014a).

There is convincing empirical evidence in favour of a positive effect of fiscal capacity on longterm economic performance, as well as a complementarity between fiscal capacity, state development, and institutional quality (Besley and Persson, 2010; Dincecco and Katz, 2016; Dincecco and Prado, 2012). However, there is little evidence on the causal link between fiscal capacity and social protection expenditure across the developing world where the majority of the poor live. The objective of this paper is to investigate the causal relationship between the fiscal capacity of the state and its social protection expenditure, hypothesizing that fiscal capacity is necessary but not sufficient for resource allocation in this category. Consequently, we also investigate the role of democracy, the quality of government, inequality, and conflict in determining the amount of social protection spending.

In general, fiscal capacity is an indication of the level of development of a country's fiscal system; in other words a more general indicator of state capacity. It could be seen as a proxy for the government's ability to implement complex policies (Rogers and Weller 2013). The relationship between fiscal capacity and social protection expenditure seems straightforward; however it has complexity. First, fiscal capacity, by providing the necessary resources, directly allows implementation of social protection programmes which, in turn, ensure the provision of public goods for the poor in particular. Second, fiscal capacity is crucial for the creation and maintenance of a qualified and efficient bureaucracy able to implement government policies and programmes. Finally, a strong fiscal capacity, along with effective constraints on the executive, is also indicative of a functional bargain between the state and the economic elites, which not only facilitates taxing the higher income group but also can promote the implementation and success of policies (Papadia 2016). Developing countries systematically seem to have lower fiscal capacity and smaller government size relative to developed countries and emerging economies (see Table 1). A weaker fiscal capacity diminishes state capacity in its multifarious functions, including social protection spending.

Another crucial determinant of social protection spending is the state's commitment to inequality reduction. It is argued that higher per capita income is associated with more fiscal capacity, but social protection expenditure does not always go up accordingly, but is a matter of politics. Table 1 indicates that richer countries tend to have greater tax capacity and more social protection spending; among developing countries low-income nations have lesser fiscal capacity, and lower social protection expenditure, compared to middle-income countries like Argentina and Brazil. South Africa has more fiscal capacity and greater social protection expenditure compared to the rest of the sub-Saharan region, both due its relative affluence and its unique political history. Ghana has greater social sector spending as a proportion of gross domestic product (GDP) than India in 2010, even though India's revenues and government spending are greater, due to India's higher military expenditure. Similarly, the Congo, despite having substantial fiscal capacity by regional standards, has lower social sector spending. Therefore, the capacity to spend in this direction needs to be reinforced by political will, and the right admixture of institutions and political competition. 
Table 1: State capacity in selected OECD and non-OECD countries in 2010

\begin{tabular}{|c|c|c|c|}
\hline Country & $\begin{array}{l}\text { Government revenue } \\
\text { (\% of GDP ) }\end{array}$ & $\begin{array}{l}\text { Government expenditure } \\
\text { (\% of GDP ) }\end{array}$ & $\begin{array}{l}\text { Social protection } \\
\text { expenditure (\% of GDP) }\end{array}$ \\
\hline \multicolumn{4}{|l|}{ OECD } \\
\hline United Kingdom & 36.47 & 46.33 & 23.56 \\
\hline Germany & 43.59 & 47.87 & 25.89 \\
\hline Japan & 29.64 & 39.01 & 16.23 \\
\hline Australia & 32.01 & 36.77 & 18.16 \\
\hline Canada & 38.26 & 43.82 & 18.14 \\
\hline Sweden & 50.44 & 50.63 & 27.56 \\
\hline \multicolumn{4}{|l|}{ Non-OECD } \\
\hline Argentina & 37.2 & 38.78 & 18.13 \\
\hline Bangladesh & 11.51 & 14.59 & 2.69 \\
\hline Brazil & 36.63 & 39.44 & 21.29 \\
\hline China & 20.19 & 22.47 & 6.83 \\
\hline Congo, Dem. Rep. & 33.09 & 31.58 & 3.71 \\
\hline Ecuador & 34.01 & 35.65 & 4.37 \\
\hline Ethiopia & 17.28 & 18.61 & 3.17 \\
\hline Ghana & 16.74 & 23.92 & 5.39 \\
\hline India & 18.82 & 27.98 & 2.64 \\
\hline Indonesia & 17.02 & 18.23 & 2.63 \\
\hline Kenya & 24.6 & 29.66 & 2.61 \\
\hline Malaysia & 24.78 & 28.53 & 2.89 \\
\hline Morocco & 27.53 & 31.9 & 6.57 \\
\hline Peru & 19.99 & 20.27 & 6.85 \\
\hline Senegal & 21.96 & 27.18 & 5.34 \\
\hline South Africa & 27.46 & 32.31 & 9.79 \\
\hline Uganda & 14.96 & 19.69 & 3.46 \\
\hline Viet Nam & 27.87 & 33.06 & 6.28 \\
\hline
\end{tabular}

Note: OECD—Organisation for Economic Co-operation and Development.

Source: Author's calculation based on IMF (n.d.) and ILO (2014a) data.

This leads us to political economy considerations, as the choice and implementation of policies by the state are fundamentally the outcome of strategic interaction between different factions with different interests. The pressure for redistribution results in the initial democratic contract (Acemoglu and Robinson 2009), with some power transferred to the less affluent and consequently some redistribution. Downs' (1957) famous median voter theory suggests that the median voter's preferences prevail in a democracy. Meltzer and Richard (1981) suggest that increases in the size of government in democracies are due to median voter pressure for redistribution. This is either due to the extension of the franchise (which lowers the median voter's income relative to the national mean income) or occurs when economic growth or transformation raises the average or mean income above that of the median voter, implying greater inequality. Dodlova and Giolbas (2016) find some evidence supporting the Meltzer and Richard (1981) median voter thesis, but encounter difficulties in satisfactorily identifying the link between changes in inequality and redistributive transfers. 
The hypothesis that increased democracy brings forth greater social sector spending in Latin America and the Caribbean is borne out by findings in Snyder and Yackovlev (2000), Mayoral and Nabernegg (n.d.), but less strongly in Huber et al. (2004), particularly during democratic transitions (when political inclusion is rising), and especially for expenditure on health and education relative to social protection per se. Shonchoy (2010), while analysing total government expenditure in developing countries, also finds total spending positively related to democracy. Dodlova and Lay (2016) argue that democracies, compared to autocracies, are more likely to institute pro-poor transfers; autocracies provide social protection mainly as a response to revolutionary threats. Programmes under autocracies, however, are likely to be less conditional and attract larger budgets. Egger et al. (2016) demonstrate that, besides political factors, there may also be geographical spread from one country to another of social protection type expenditures via a demonstration effect throughout history; this mechanism may account for its recent emergence or surge in developing countries, particularly in Latin America. Arguably, the fragility of social protection spending in the advanced economies that are also democracies in our recent age of globalization is due to the strengthening of the political clout of the wealthy, as well as the breakdown of earlier redistributive social contracts and median voter power. ${ }^{1}$

We advance our knowledge of the determinants of social protection expenditure by examining the causal relationship between fiscal capacity and social protection expenditure, along with the role of institutions (polity and quality of government) in a cross-section of developing countries from 1990 to 2010. Apart from this, we examine the relation between the degree of social protection expenditure and inequality, as well as conflict across a range of developing countries pertaining to both fiscal capacity and the political will to spend on this category of expenditure. We employ panel data instrumental variables (IV) methods to address endogeneity problems in estimating the causal impact of fiscal capacity on social protection expenditure. We also control for the relevant covariates found in the literature and carry out robustness checks on our main results.

Our findings suggest that greater fiscal capacity robustly raises social protection spending, as does higher per capita income, whereas greater external debt servicing inhibits this category of expenditure. Rising democratization enhances social sector spending; the presence of greater democracy and higher fiscal capacity could reinforce this effect. We also find that more equal societies spend more on social protection, and conflict puts upward pressure on social sector spending, although not to a statistically significant extent. The rest of the paper is organized as follows: section 2 presents the theoretical and empirical underpinnings for our investigation; section 3 outlines our model specification, data, and econometric strategy; section 4 presents our econometric results; and finally section 5 contains some conclusions.

\footnotetext{
1 The growing share of wealth relative to national income, according to Piketty (2014), resulting in the functional distribution of income becoming less favourable to labour, is central to these developments.
} 


\section{Theoretical and empirical underpinnings for social protection expenditure}

We first turn to the economic rationale for social protection, which essentially revolves around the debate about the nexus between income and wealth inequality on the one hand, and economic growth and welfare on the other hand. ${ }^{2}$

The developing world has made major strides in reviving growth and poverty reduction since the beginning of the new millennium. But major concerns remain about groups that are being left behind in this march towards greater prosperity. This includes the growing tide of inequality throughout the world during our present era of globalization (Piketty, 2014; Stiglitz, 2012), with some exceptions in selected Latin American countries like Brazil. The chief misgivings regarding these developments are to do with the income and wealth share of the richest 1 per cent or 10 per cent of the population. If we take a truly cosmopolitan view, treating the entire planet as a single entity, global inequality may have declined by about 2 percentage Gini points between 1988 and 2008 to around 70.5 (Lakner and Milanovic, 2015), but this finding, as the authors point out, may mask the serious underestimation of the income of the top decile in the income distribution, who are often missed out in household surveys. Jorda and Niño-Zarazúa (2016) indicate that once the missing income of the richest is taken into account (using tax records in selected countries) the global income distribution looks different, and global inequality estimates based on household surveys alone have a downward bias of 15-42 per cent, especially for low-income countries and sub-Saharan Africa. Accompanying this rise in inequality has been the increased informalization of work, combined with the growth of vulnerable jobs without regulatory protection and social insurance (ILO 2014b). In addition, the wealth share of the richest 1 per cent in the world is greater than the rest of the population's (99 per cent) total wealth, according to some sources (Oxfam 2016); according to Credit Suisse (2010) less than 1 per cent of the richest in the world own more than one-third of the world's wealth. The power thus conveyed is bound to impact on policymaking, particularly on tax policies that permit the richest to pay lower taxes on their wealth, as well as preventing policy coordination between nations to prevent tax avoidance. The political influence of the wealthy is growing, as remarked upon by Stiglitz (2012), and a recent Oxfam (2016) report.

Our first concern is with the efficiency aspects of the growth and inequality relationship, and hence, indirectly, the merits of social protection in redressing inequality. Classical and neoclassical growth theories emphasized the role of saving (invested in productive capacity), chiefly by the owners of capital, in generating growth. In this connection, a greater degree of inequality may accompany initial growth spurts, as exemplified by the famous Kuznets (1955) hypothesis about the inverted U-shaped relationship between income inequality and per capita income. As growth accelerates, inequality first rises, but after reaching a certain peak in average income, inequality begins to decline. This pattern certainly explains the growth history of the earliest industrialized nations, such as the UK and the USA, as demonstrated by Kuznets (1955). Since the 1980s, however, inequality is widely regarded to be on the increase again in most advanced industrialized nations. Inequality can facilitate greater economic growth if capitalists are more innovative and save a greater proportion of their income compared to other classes (Kaldor, 1957). But this may not apply if the greater inequality is a result of the acquisition of a rent by the highest income earners, rather than returns from productive investment in manufacturing, as is the case for much of the financial investments of the wealthiest at present (see Orhangazi 2008 on financialization).

\footnotetext{
${ }^{2}$ As far as developing countries are concerned, there was a greater consensus, until recently, about the need to reduce poverty via 'pro-poor' growth relative to the importance attached to lowering inequality; see, for example, remarks made by Anne Krueger of the IMF in 2002 (https://www.imf.org/external/np/speeches/2002/092602a.htm, accessed on 14 January 2015).
} 
Moreover, the Kuznets relationship does not seem to hold for the post-Second World War growth experiences in East Asia (Alesina and Rodrik 1994). In contrast with the theories of growth embodying exogenous technical progress, endogenous growth theories highlight the importance of human capital in promoting growth, thus implying the positive role of publicly funded education. Easterly (2007) demonstrates that a higher middle class share of income does promote growth, because the middle classes traditionally clamour for more growth-enhancing public goods, including publicly funded education and health care.

Dabla-Norris et al. (2015) and Ostry et al. (2014) show that the recent growth experiences of a cross-section of developed and developing countries suggest that inequality is harmful to growth prospects. This could be because greater inequality leaves economies more prone to financial crises, ${ }^{3}$ greater inequality results in less human capital accumulation, and because inequality contains within it the seeds of conflict, which is harmful for growth. On the causes of recent rises in income inequality, Dabla-Norris et al. (2015) point out that unskilled labour-saving technical progress, financial globalization (but not trade openness), and less regulation of labour markets, including the informalization of work, are the chief culprits.

In empirical models, redistributive policies, including social protection expenditures, appear to no longer harm growth prospects (Ostry et al. 2014) in recent years across countries. Traditionally, it was believed that greater government consumption was negatively correlated with growth (Tavares and Wacziarg 2001), because of crowding-out effects and distortions to incentives. Thus, redistributive policies financed by taxation were distortion-inducing, even when they resulted in greater equity and social justice. Economic efficiency and equity needed to be separated, and furthermore there was an efficiency-equity trade-off (see Okun 1975), empirical evidence for which seems to have weakened in recent years, linked, among other phenomena, to new forms of market failure.

Market failures emanating from credit and labour market imperfections can result in harmful inequality, justifying intervention and redistribution. Among such failures is the presence of adverse selection (Stiglitz 2012), which makes the competitive equilibrium and its associated income distribution no longer Pareto optimal. Adverse selection in credit and labour markets can lead to inefficient outcomes for the economy that also exacerbate both poverty and inequality, as the poor are credit rationed, have less access to education, and experience disproportionate downward pressure on their real wages. Stiglitz and Weiss (1981) built the seminal analytical model of credit rationing with adverse selection, which disadvantages the poor and is of considerable empirical and policy relevance in developing countries. Bénabou and Tirole (2013) construct an analytical model of excessive bonus pay for the skilled, and under-incentivization of the low paid, with substantial welfare losses for the economy.

Traditional arguments against excessive inequality were grounded in purely 'equity' considerations based on society's aversion to highly unequal outcomes. A modicum of unequal outcomes as a reward for differential effort, talent and risk-taking can be regarded as fair, but what is both unjust and inefficient is inequality of opportunity (Roemer 1998). This may be rooted in either systematic discrimination or unequal access to opportunities, such as education. It can be argued that present day trends in the distribution of income, with the accelerating share of the top 1 per cent in the global income distribution, do produce inequality of opportunity and hamper intergenerational mobility, particularly because much of the wealth of the wealthiest is principally attributable to a

\footnotetext{
${ }^{3}$ This is because the extremely wealthy demand a high return to their financial investments, and the financial debt burden of the relatively poor, if securitized, can make economies more prone to financial crises, which in turn can cause major recessions.
} 
rent earned from speculative financial investments. In the ultimate analysis, in the presence of many market imperfections, adverse selection, substantial economic rents, and inequality of opportunity, the separability between the efficiency and equity arguments against inequality cannot be maintained, but above all make social protection and redistributive policies justifiable. Gebregziabher and Niño-Zarazúa (2014) present evidence to suggest that social spending improves the inequality-adjusted human development index of the United Nations Development Programme (UNDP), and public health expenditure reduces child mortality.

Where there is a distributive conflict between the haves and the have nots, a high degree of inequality may damage future growth prospects (Alesina and Rodrik 1994), thus explaining the redistributive policies pursued after the Second World War in North-East Asia (particularly with regard to land redistribution) prior to these countries' growth spurt, and the absence of a Kuznets relation there. Rodrik (1999) argues that social conflict measured by indicators such as inequality, unless managed by well-functioning institutions, can lead to growth collapses. In other words, persistent inequality destabilizes society and the social contract; this may produce social conflict, even if it is not full-blown armed conflict. ${ }^{4}$

In summary, a degree of social protection is necessary to avoid distributive and social conflicts, particularly with greater globalization and when the tide of inequality is on the rise. As far as the determinants of social protection expenditure are concerned, it is predicated both on economic capacity - the fiscal capacity of the state - as well as political factors, which are chiefly about how the state and society respond to inequality and poverty, but also related to how well the state functions (the quality of governance). Thus both economic capacity and political will, the two ingredients making up state capacity, determine the existence and extent of social protection expenditures.

\section{$3 \quad$ Model specification and econometric methods ${ }^{5}$}

\subsection{Model specification and data}

Our empirical hypothesis is that social protection expenditure is a function of state capacity: which has economic and political dimensions. To investigate primarily the impact of fiscal capacity and institutions on the allocation of social protection spending, we make use of a panel dataset comprised of 97 developing countries from 1990 to 2010. A broad definition of social protection can, therefore, include social insurance payments (pensions, unemployment benefits, labour protection schemes) that are contingent on certain events, measures to reduce poverty (such as food aid conditional on school attendance, public works programmes), and arguably also public expenditure on items such as health. Note that we are not just interested in the presence of social spending, but mainly the extent of social sector expenditure, measured by the ratio of this variable to GDP. Our definition of social spending is drawn from the ILO database contained in a report (ILO, 2014a) because it has maximum country coverage over time for developing countries. This data source has cross-country comparable data for public expenditure on social protection and health; it is also utilized as the dependent variable in the cross-country study by Gassman et al. (2016). ${ }^{6}$ Data on this variable is only available for every five-year interval point during the period

\footnotetext{
${ }^{4}$ Inequality between distinct ethnic groups, a concept known as horizontal inequality, can be a major cause of civil war; see, for example, Murshed (2010: ch. 3).

${ }^{5}$ Annex Table A1 gives details of our data sources and Annex Table A2 gives the list of countries in our sample.

${ }^{6}$ Their study is a cross-sectional analysis, whereas our analysis is a panel covering the 1990 to 2010 period.
} 
1990-2010, which entails five observation points. To match with the dependent variable, we take five-year average of our data on other explanatory and control variables.

To be more specific in carrying out econometric estimation, we estimate several models to examine our hypotheses. On the economic capacity side, our first hypothesis is that the extent of social sector spending depends upon the resources available to the state in which we are interested in looking at the causal relationship between these two variables. To this end, one of our main independent variables is fiscal capacity, measured by government revenues over national income. Here our variable of interest, government revenue, is broadly defined and includes all types of taxes, social contributions, grants receivable, and other revenue. Our choice of variable is arguably suitable as the social protection expenditure largely depends on the total revenue of a particular country.

Although fiscal capacity is in principle correlated with per capita income, we do not find this to be the case, and we include per capita income as a control variable for the size of the economy; as income per capita rises beyond a certain point, social sector spending can rise more than proportionately, as in the case of OECD countries. The resources available to the state may be (substantially) diminished by the burden of servicing debt incurred in the past; to this end we incorporate debt servicing to national income ratios as an explanatory variable. Inflation, although it yields seigniorage revenues in some instances, may compromise government spending, which might need to be curtailed to facilitate an anti-inflation macroeconomic stance; thus it is also incorporated as an explanatory variable in our model. An additional variable of interest may be growth in population, which may be an indication of increasing dependency and a growing labour force. This may result in the growth of GDP, but if social protection expenditure does not rise proportionately, it will have a negative impact on our dependent variable.

The first, as well as our base model, takes the following form:

$$
Y_{i t}=\beta_{0}+\beta_{1} F_{i t}+\beta_{1} X_{i t}+u_{i t}(1)
$$

In equation (1), $i$ and $t$ indicate country and year respectively, $Y_{i t}$ stands for public expenditure on social protection. $F_{i t}$ is our main variable of interest, fiscal capacity (defined as total revenue including, taxes, royalties, and aid as a share of GDP), and $X_{i t}$ is the vector of all control variables namely, per capita GDP, inflation, debt servicing as a proportion of gross national income (GNI), and population growth. In the above equation, $u_{i t}$ comprises both time-invariant unobserved country-specific effects (fixed effects) $e_{i}$, and a time-variant unobserved component $v_{i t}$.

On the political side, in accordance with the literature on the determinants of social sector expenditure, we incorporate the degree of democracy, as democracies are more likely to spend on social protection. This may be all the more important following the second wave of democratization following the end of the Cold War. We deploy the well-known hybrid Polity 2 combined scores of democracy (ranging from 0 at the bottom end to 10 for perfect democracies) and autocracy (extending from -10 for the worst to 0 ). It is also important to examine the effect of institutional quality, as this could have an impact on social sector expenditure. To this end, indicators of the quality of government, which is the mean value of the International Country Risk Guide (ICRG) variables corruption, law and order, and bureaucratic quality, scaled $0-1$, is taken, with a higher value indicating improved governance (see Dahlberg et al. 2013 for details). In relation to the argument regarding political commitment for social protection expenditure, we introduce the institutional variable as a separate explanatory variable in the second model, along with other control variables of the first model. Moreover, inclusion of institutional variable in the base model implies that better institutions in terms of political will or quality of government may 
reinforce the effect of fiscal capacity on social protection spending. Our second model can be expressed as follows.

$$
Y_{i t}=\beta_{0}+\beta_{1} F_{i t}+\beta_{2} P_{i t}+\beta_{3} X_{i t}+u_{i t}(2)
$$

In equation (2), $P_{i t}$ represents the polity and quality of government variable, run in separate models as alternative estimates of each other.

Arguably, an important determinant of social sector spending is inequality, as discussed in the preceding section. Social sector spending redresses inequality, but current inequality (rather than past inequality) may reflect society's or the ruling class's attitude to inequality: a more inequalityaverse society may engage in greater social spending. If so, then the inequality variable may appear with a negative sign. We utilize the income Gini measure of inequality drawn from the World Bank database, as it is the most complete dataset compared to other sources, such as UNU-WIDER, and also does not suffer from methodological flaws such as in, say, the Solt (2014) data. In addition, we also utilize the Palma (2011) ratio. This is a measure of inequality, which is a ratio of the income shares in national income of the top 10 per cent of households relative to the bottom 40 per cent of households. Arguably, this will capture the effect of changes in inequality over time (Cobham and Sumner 2013). Over time, inequality will also capture the effect of increased globalization on the distribution of household income via alterations in the functional distribution (skilled and unskilled labour shares) of income. Thus, inequality can serve as a proxy for greater globalization, and for examining Rodrik's (1998) argument that more open economies need to have bigger government expenditure in order to cushion the effect of external shocks. To capture the effect of inequality, we include an inequality variable in the third model after controlling for explanatory and control variables. Furthermore, introducing an inequality variable in the base model shows how society's attitude towards inequality affects the role of fiscal capacity on social protection spending. We can show this model in the following way. In equation (3), $I_{i t}$ represents the inequality variable in the form of either the Gini coefficient or the Palma ratio, which are run in separate models as alternative estimates of each other.

$$
Y_{i t}=\beta_{0}+\beta_{1} F_{i t}+\beta_{2} I_{i t}+\beta_{3} X_{i t}+u_{i t}(3)
$$

Another independent variable that may be important is the presence of civil war and armed conflict. Many developing countries have experienced this phenomenon, and civil war, or its causes based on inequality or relative deprivation, may necessitate greater social protection spending, particularly after its cessation. Data on this was obtained from the Uppsala Conflict Data Program (UCDP) dataset (for the definition of conflict see Annex Table A1). The presence of conflict is indicated via a dummy variable ( 1 if there is conflict, 0 otherwise). In the fourth model, we introduce the conflict variable as a separate explanatory variable and it can be written as follows, where $\mathrm{C}_{i t}$ denotes conflict variable:

$$
Y_{i t}=\beta_{0}+\beta_{1} F_{i t}+\beta_{2} C_{i t}+\beta_{3} X_{i t}+u_{i t}(4)
$$

In the third and fourth models we do not include three variables - namely institution, conflict, and inequality - all together in same model to avoid multicollinearity and simultaneity biases.

\subsection{Econometric methods}

As a natural starting point for panel data analysis, we begin our estimation applying pooled ordinary least square (OLS) methods to the above specification. The advantage of using pooled OLS is that it uses more information by combining cross-sectional and time series observations to get more reliable estimates of the parameters compared to cross-sectional OLS. Pooled OLS provides 
unbiased and consistent estimates as long as the composite error term $u_{i t}$ is uncorrelated with $X_{i t}$. However, the presence of unobserved time-invariant country-specific characteristics or fixed effects $e_{i}$ in the composite error term $u_{i t}$ makes it likely to be correlated with the explanatory variables. This problem can be mitigated employing fixed effects (FE) technique, which removes the unobserved country-specific heterogeneity by within-transformation effects. However, the FE model eliminates a significant amount of the variation of the explanatory variables leading to measurement error. The FE model does not permit estimating the effect of time-invariant independent variables. As an alternative to the FE model, a random effects (RE) specification can be employed. But the RE model relies on a stronger assumption, that is, that the unobserved country-specific effect $e_{i}$ is random and independent of $v_{i \text { r }}$ In other words, country-specific unobserved heterogeneity is uncorrelated with independent variables. If there is no omitted variable bias, RE gives unbiased estimates of the coefficients and produces the smallest standard errors. Although the RE model provides better efficiency (smaller standard errors) and allows coefficients of time-invariant covariates to be estimated, the assumption of $e_{i}$ being uncorrelated with $X_{i t}$ is often violated, so it is more likely that $\mathrm{RE}$ estimates suffer from omitted variable bias. The trade-off between FE and RE is thus unbiasedness versus efficiency. To compare these three specifications, the Lagrange multiplier (LM) test can be used to test the null hypothesis of no random effect and the Hausman test can be used to test the null hypothesis of individual effects uncorrelated with any of the regressors. Rejection of the null hypothesis in the former test, and the failure to reject the null hypothesis in the latter, indicate that the RE model is appropriate.

We now turn to the potential problem of endogeneity to estimate the causal effect of state capacity on social spending expenditure. The presence of endogeneity makes regression estimates a measure of only the magnitude of association rather than the magnitude and direction of causation. Fiscal capacity measured by revenue as a share of GDP is likely to be endogenous for three possible reasons: reverse causality between fiscal capacity and social sector expenditure, model misspecification or omitted variable problem, and measurement error. There is a possibility that state capacity and social spending expenditure are jointly determined by some other factors. The instrumental variable (IV) technique can be used in the above three models to address this endogeneity problem in our empirical analysis. So we estimate the pooled OLS using IV or twostage least squares (2SLS), random effect IV (RE IV) and fixed effect IV (FE IV). ${ }^{7}$

Successful implementation of the IV method relies on three identifying assumptions. The first is instruments' relevance or a strong first stage. That is, selected instruments must be highly correlated with an endogenous variable. Second, instruments must be exogenous, which means they are uncorrelated with the error term. This is also known as testing for over-identifying restrictions. Finally, instruments must meet exclusion restrictions, which means that instruments do not appear as separate regressors in the second stage regression. In summary, we can say that valid, relevant and strong instruments affects the dependent variable only through the endogenous variable. We employ two instruments for revenue as share of GDP: the share of agriculture in GDP as well as the share of natural resource rents in GDP. In our case, the instruments appear to be sufficiently correlated with state capacity but insignificantly correlated with social expenditure after controlling for covariates. Both of these variables are highly correlated with fiscal capacity, the latter (natural resource rents) contributes positively to revenues, whereas the former may have an adverse effect on revenues if land taxes are low or avoided. The share of agriculture in GDP is largely unrelated to social sector expenditure, whereas resource rents are related to such expenditure only in highly autocratic states without representative government (Ross 2012). The

\footnotetext{
${ }^{7}$ The presence of country FE indicates the FE model as the preferred approach to account for FE-related endogeneity. The Hausman test (not reported here) in most cases favoured FE specifications, but we prefer to present all the models for clarity.
} 
identifying assumptions of these instruments are tested using available statistical tests (the Kleibergen-Paap Wald test, the Cragg-Donald F-statistic, the Sargan-Hansen test, etc.) and relevantly discussed in the following results section. In all our models, standard errors are countrycluster corrected robust standard errors.

We largely follow Gebregziabher and Niño-Zarazúa (2014) and Chiripanhura and Niño-Zarazúa (2015) to conduct severe robustness checks to test the validity of our findings. This includes alternative sample analysis (restricting the sample to low- and middle-income countries and less democratic countries), using an alternative measure of state capacity ${ }^{8}$ and use of alternative estimators. To circumvent finite-sample biases in the IV method, Limited Information Maximum Likelihood (LIML) methods and continuously updated Generalized Method of Moments estimators (CUE) have been employed for better finite-sample performance. According to Hahn et al. (2004), LIML and CUE tend to perform better than IV methods in the presence of weak instruments. Apart from LIML and CUE, we have also used two-step GMM (GMM-IV) and Fuller's modified LIML (hence after Fuller) in our robustness analysis.

\subsection{Descriptive statistics}

Table 2 presents the descriptive statistics of our study sample. It suggests that there is an increase between 1990 and 2010 in the average share of national income devoted to social protection and health expenditure, although the country coverage for the latter year is greater. There is also a slight increase in the average fiscal or revenue capacity. The burden of debt servicing also appears to have declined.

Compared to 1990, the degree of democracy has increased in 2010. Whereas the average for the sample would indicate an autocratic score of -2.1in 1990, this number increased to about 2.6 in 2010, as a result of the third wave of democratization in developing countries in the 1990s. ${ }^{9}$ Yet, most developing countries remain imperfect democracies or anocracies, suggesting a mixture of periodic multi-party elections (often marred by electoral violence and rigging) with autocratic executives, and that is why the polity score is very rarely above 8 . There is little discernible change in the quality of governance, inequality measures (Gini and the Palma ratio), as well as the incidence of high-intensity conflict. The inequality measures suffer from the drawback that the richest households in many countries tend to be unrepresented in household surveys.

\footnotetext{
${ }^{8}$ In this case, share of agriculture in GDP is only used as an instrument.

${ }^{9}$ Arguably, the average democracy score across the developing world for 2010 would be higher if countries in the Middle East and North Africa were excluded.
} 
Table 2: Summary statistics

\begin{tabular}{lcccc}
\hline Variables & \multicolumn{2}{c}{1990} & \multicolumn{2}{c}{2010} \\
& Mean & SD & Mean & SD \\
\hline Social protection expenditure (\% GDP) & 4.36 & 3.964 & 6.84 & 4.945 \\
Base variables & & & & \\
Fiscal capacity (revenue as \% GDP) & 23.45 & 8.216 & 26.43 & 10.003 \\
Population growth (\%) & 2.35 & 1.204 & 1.69 & 1.066 \\
Per capita income/GDP (in constant price of year 2005) & 1585.35 & 1408.05 & 2444.86 & 2450.538 \\
Rate of inflation (\%) & 121.66 & 568.367 & 8.67 & 5.346 \\
Debt servicing (\% GNP) & 6.59 & 5.764 & 3.92 & 5.729 \\
Institutional variables & & & & \\
Polity (or degree of democracy) & -1.79 & 6.417 & 2.35 & 5.869 \\
Quality of government & 0.41 & 0.173 & 0.42 & 0.098 \\
Other proximate variables & & & & \\
Conflict (Yes = 1) & & & & \\
Income inequality (Gini index) & 0.28 & 0.398 & 0.28 & 0.411 \\
Income inequality (Palma ratio) & 42.24 & 9.828 & 41.996 & 8.636 \\
\hline
\end{tabular}

Source: Authors' calculation based on panel dataset.

\section{$4 \quad$ Results}

Before presenting the regression results, we discuss the justification for using share of agriculture in GDP and the share of natural resource rent in GDP as our instruments for fiscal capacity. First, F-statistics of the Cragg-Donald test of weak identification well exceeds the rule of thumb value (10) in all models (OLS, RE, and FE). The finite-sample corrections of this test, the KleibergenPaap Wald statistic, also easily exceeds conventional critical values. This suggests the strong partial correlation between the included endogenous variable and the excluded instruments in our study. The first-stage results (not reported here) suggest that our instruments are individually correlated with fiscal capacity. The null hypothesis of zero correlation between the instruments and fiscal capacity in Kleibergen-Paap rk LM under-identification test is also strongly rejected. Finally, the Hansen test of over-identifying restrictions suggests that the validity of the instruments cannot be rejected. These indicate that the instruments have a strong association with fiscal capacity but are not significantly correlated with social expenditure once the relevant explanatory variables are controlled for, which endorses the validity of our specifications.

We now start the discussion of our results by presenting the findings of the baseline model in equation (1). It should be noted that, although we report results of all the models, our preferred approach is FE IV, or column (6) in each table, to analyse our results. 
The estimated coefficient on fiscal capacity is positive and significant across all models. This suggests that fiscal capacity is important in sustaining social protection spending. As per the results shown in column (6) of Table 3, if there is an increase in fiscal capacity (as percentage share of GDP) by 1 per cent, social protection expenditure increases by 0.125 percentage points. The magnitude of the coefficient for fiscal capacity varies accross models, which signifies the role of our other explanatory variables, namely, institutions, inequality, and conflict.

Table 3: Role of fiscal capacity in social protection expenditure

\begin{tabular}{|c|c|c|c|c|c|c|}
\hline Explanatory variable & $\begin{array}{l}\text { OLS } \\
\text { (1) }\end{array}$ & $\begin{array}{l}\text { OLS IV } \\
\text { (2) }\end{array}$ & $\begin{array}{l}\text { RE } \\
\text { (3) }\end{array}$ & $\begin{array}{l}\text { RE IV } \\
\text { (4) }\end{array}$ & $\begin{array}{l}\text { FE } \\
\text { (5) }\end{array}$ & $\begin{array}{l}\text { FE IV } \\
(6)\end{array}$ \\
\hline \multirow[t]{2}{*}{ Fiscal capacity } & $0.195^{\star * *}$ & $0.195^{\star *}$ & $0.108^{* * *}$ & $0.169^{\star * *}$ & $0.076^{* * *}$ & $0.125^{\star *}$ \\
\hline & $(0.042)$ & $(0.092)$ & $(0.027)$ & $(0.055)$ & $(0.025)$ & $(0.058)$ \\
\hline \multirow[t]{2}{*}{ Population growth } & $-1.110^{\star \star \star}$ & $-1.301^{\star * *}$ & $-0.608^{* * *}$ & $-0.796^{\star * *}$ & $-0.414^{* *}$ & $-0.521^{\star \star \star}$ \\
\hline & $(0.323)$ & $(0.321)$ & $(0.199)$ & $(0.188)$ & $(0.167)$ & $(0.179)$ \\
\hline \multirow[t]{2}{*}{ Per capita income } & 0.000 & 0.000 & $0.001^{* * *}$ & $0.001^{* * *}$ & $0.001^{* * *}$ & $0.001^{* * *}$ \\
\hline & $(0.000)$ & $(0.000)$ & $(0.000)$ & $(0.000)$ & $(0.000)$ & $(0.000)$ \\
\hline \multirow[t]{2}{*}{ Inflation } & 0.005 & 0.005 & -0.002 & -0.001 & $-0.003^{* * *}$ & -0.002 \\
\hline & $(0.005)$ & $(0.005)$ & $(0.007)$ & $(0.007)$ & $(0.001)$ & $(0.002)$ \\
\hline \multirow[t]{2}{*}{ Debt servicing } & -0.065 & -0.049 & $-0.091^{\star \star *}$ & $-0.080^{* *}$ & $-0.101^{* *}$ & $-0.097^{\star *}$ \\
\hline & $(0.064)$ & $(0.066)$ & $(0.029)$ & $(0.034)$ & $(0.041)$ & $(0.044)$ \\
\hline \multirow[t]{2}{*}{ Constant } & $2.564^{\star *}$ & 2.771 & $3.241^{* * *}$ & $2.232^{\star \star}$ & $2.908^{\star \star \star}$ & - \\
\hline & $(1.006)$ & (2.104) & $(0.724)$ & $(1.047)$ & $(0.900)$ & - \\
\hline Observations & 351 & 336 & 351 & 336 & 351 & 335 \\
\hline R-squared & 0.409 & 0.463 & 0.345 & 0.429 & 0.289 & 0.291 \\
\hline Country FE & NO & NO & NO & NO & YES & YES \\
\hline Number of countries & 97 & 94 & 97 & 94 & 97 & 93 \\
\hline Cragg-Donald F-stat & & 30.79 & & 35.34 & & 29.38 \\
\hline Kleibergen-Paap F-stat & & 19.12 & & 32.32 & & 20.43 \\
\hline Kleibergen-Paap LM-stat & & 14.34 & & 20.21 & & 14.38 \\
\hline $\begin{array}{l}\text { Kleibergen-Paap LM-stat ( } p \text { - } \\
\text { value) }\end{array}$ & & 0.000770 & & 0.0000 & & 0.000753 \\
\hline Hansen test ( $p$-value) & & 0.385 & & 0.133 & & 0.119 \\
\hline
\end{tabular}

Source: Authors' calculation based on panel dataset. 
The debt servicing variable is negative throughout, and significant in the random and FE estimations, indicating that it too may be significant in retarding social sector spending. The coefficient on population growth is negative and significant throughout. As indicated earlier, this may be due to the fact that a growing population leads to an increase in national income, but social spending may not be rising in proportion; in some instances per capita income and the revenues of the state do not rise in proportion to population growth. The coefficient on per capita GDP is positive throughout, and significant in the fixed and random effects estimates. This means that growing mean income leads to greater social sector spending, which is why richer countries have proportionately bigger governments. Inflation turns out to have a negative, but mainly insignificant, sign in the panel data methods, indicating that greater inflation is accompanied by contractionary fiscal policy, lowering social sector spending.

Our institutional variables (both polity and quality of government) appear to be positive; only polity is found to be statistically significant however (Tables 4 and 5). As noted above, most developing countries are imperfect democracies, combining characteristics of democracy (elections) with authoritarian executives. The degree of democracy is positively related to social sector spending, and the coefficient is significant at less than 1 per cent significance level. This finding is in line with the consensus in the literature that, in general, greater democracy promotes higher social sector spending. The other macroeconomic covariates remain largely unchanged from the baseline estimations in Table 3. In comparison with the baseline regressions in Table 3, the introduction of the degree of democracy in Table 4 leads to the dimunition of the magnitude of the coefficient on fiscal capacity in the IV panel regressions. Thus, as indicated earlier, fiscal capacity is not the only determinant of social sector expenditure, other political factors are also relevant.

Table 4: Role of fiscal capacity and democracy in social protection expenditure

\begin{tabular}{|c|c|c|c|c|c|c|}
\hline Explanatory variable & $\begin{array}{l}\text { OLS } \\
(1) \\
\end{array}$ & $\begin{array}{l}\text { OLS IV } \\
(2)\end{array}$ & $\begin{array}{l}\mathrm{RE} \\
(3) \\
\end{array}$ & $\begin{array}{l}\text { RE IV } \\
(4)\end{array}$ & $\begin{array}{l}\text { FE } \\
(5) \\
\end{array}$ & $\begin{array}{l}\text { FE IV } \\
(6)\end{array}$ \\
\hline Fiscal capacity & $\begin{array}{l}0.203^{\star \star \star} \\
(0.048)\end{array}$ & $\begin{array}{l}0.215^{\star *} \\
(0.098)\end{array}$ & $\begin{array}{l}0.109^{* * *} \\
(0.025)\end{array}$ & $\begin{array}{l}0.148^{\star * *} \\
(0.050)\end{array}$ & $\begin{array}{l}0.079^{* * *} \\
(0.025)\end{array}$ & $\begin{array}{l}0.101^{*} \\
(0.057)\end{array}$ \\
\hline Population growth & $\begin{array}{l}-1.043^{\star \star \star} \\
(0.334)\end{array}$ & $\begin{array}{l}-1.209^{\star \star \star} \\
(0.310)\end{array}$ & $\begin{array}{l}-0.620^{* * *} \\
(0.209)\end{array}$ & $\begin{array}{l}-0.802^{\star * \star} \\
(0.212)\end{array}$ & $\begin{array}{l}-0.446^{\star \star} \\
(0.170)\end{array}$ & $\begin{array}{l}-0.554^{\star \star \star} \\
(0.181)\end{array}$ \\
\hline Per capita income & $\begin{array}{l}0.000 \\
(0.000)\end{array}$ & $\begin{array}{l}0.000 \\
(0.000)\end{array}$ & $\begin{array}{l}0.001^{* * *} \\
(0.000)\end{array}$ & $\begin{array}{l}0.001^{\star * *} \\
(0.000)\end{array}$ & $\begin{array}{l}0.001^{* * *} \\
(0.000)\end{array}$ & $\begin{array}{l}0.001^{* * *} \\
(0.000)\end{array}$ \\
\hline Inflation & $\begin{array}{l}0.026^{\star *} \\
(0.011)\end{array}$ & $\begin{array}{l}0.029^{* *} \\
(0.012)\end{array}$ & $\begin{array}{l}0.000 \\
(0.009)\end{array}$ & $\begin{array}{l}0.002 \\
(0.012)\end{array}$ & $\begin{array}{l}-0.003 \\
(0.006)\end{array}$ & $\begin{array}{l}-0.002 \\
(0.008)\end{array}$ \\
\hline Debt servicing & $\begin{array}{l}-0.106 \\
(0.074)\end{array}$ & $\begin{array}{l}-0.081 \\
(0.078)\end{array}$ & $\begin{array}{l}-0.080^{* *} \\
(0.040)\end{array}$ & $\begin{array}{l}-0.071^{*} \\
(0.036)\end{array}$ & $\begin{array}{l}-0.083^{*} \\
(0.045)\end{array}$ & $\begin{array}{l}-0.086^{*} \\
(0.049)\end{array}$ \\
\hline Polity & $\begin{array}{l}0.074 \\
(0.046)\end{array}$ & $\begin{array}{l}0.071 \\
(0.052)\end{array}$ & $\begin{array}{l}0.068^{\star \star \star *} \\
(0.023)\end{array}$ & $\begin{array}{l}0.069^{\star *} \\
(0.029)\end{array}$ & $\begin{array}{l}0.072^{* \star *} \\
(0.025)\end{array}$ & $\begin{array}{l}0.073^{\star \star \star} \\
(0.027)\end{array}$ \\
\hline Constant & $\begin{array}{l}2.068^{*} \\
(1.088) \\
\end{array}$ & $\begin{array}{l}1.978 \\
(2.103) \\
\end{array}$ & $\begin{array}{l}3.162^{* \star *} \\
(0.749) \\
\end{array}$ & $\begin{array}{l}2.591^{* *} \\
(1.066) \\
\end{array}$ & $\begin{array}{l}2.902^{* * *} \\
(0.979) \\
\end{array}$ & $\begin{array}{l}- \\
- \\
\end{array}$ \\
\hline Observations & 314 & 303 & 314 & 303 & 314 & 303 \\
\hline R-squared & 0.438 & 0.486 & 0.368 & 0.436 & 0.323 & 0.335 \\
\hline Country FE & NO & NO & NO & NO & YES & YES \\
\hline Number of countries & 85 & 83 & 85 & 83 & 85 & 83 \\
\hline Cragg-Donald F-stat & & 27.48 & & 37.19 & & 29.47 \\
\hline Kleibergen-Paap F-stat & & 15.06 & & 29.80 & & 20.90 \\
\hline Kleibergen-Paap LM-stat & & 15.28 & & 19.52 & & 14.65 \\
\hline $\begin{array}{l}\text { Kleibergen-Paap LM-stat( } p \text { - } \\
\text { value) }\end{array}$ & & 0.000481 & & 0.0001 & & 0.000658 \\
\hline Hansen test ( $p$-value) & & 0.613 & & 0.324 & & 0.314 \\
\hline
\end{tabular}

Source: Authors' calculation based on panel dataset. 
In Table 5, we present our regression results where polity is replaced with quality of government based on the composite ICRG indicators of good governance. We do this omitting democracy (polity), as these two variables may be co-linear. This variable is mainly positive but insignificant. This suggests that institutional quality may have a role to play in enhancing social sector spending, but it may not be as important as the presence of democracy. In other words, spending decisions are more closely related to democracy than how well governance operates. This, however, leaves open the question regarding the quality of social sector provision, which is beyond the scope of our paper; the quality of services may be related to the standards of governance. The sign and significance of the other economic covariates are much the same as before.

Table 5: Role of fiscal capacity and quality of government in social protection expenditure

\begin{tabular}{|c|c|c|c|c|c|c|}
\hline Explanatory variable & $\begin{array}{l}\text { OLS } \\
\text { (1) }\end{array}$ & $\begin{array}{l}\text { OLS IV } \\
(2)\end{array}$ & $\begin{array}{l}\text { RE } \\
(3)\end{array}$ & $\begin{array}{l}\text { RE IV } \\
\text { (4) }\end{array}$ & $\begin{array}{l}\text { FE } \\
(5)\end{array}$ & $\begin{array}{l}\text { FE IV } \\
(6)\end{array}$ \\
\hline Fiscal capacity & $\begin{array}{l}0.230^{\star \star \star} \\
(0.061)\end{array}$ & $\begin{array}{l}0.106 \\
(0.085)\end{array}$ & $\begin{array}{l}0.106^{\star *} \\
(0.041)\end{array}$ & $\begin{array}{l}0.120^{*} \\
(0.071)\end{array}$ & $\begin{array}{l}0.071^{\star *} \\
(0.035)\end{array}$ & $\begin{array}{l}0.124 \\
(0.090)\end{array}$ \\
\hline Population growth & $\begin{array}{l}-1.369^{* * *} \\
(0.412)\end{array}$ & $\begin{array}{l}-1.750^{* * *} \\
(0.448)\end{array}$ & $\begin{array}{l}-0.702^{* *} \\
(0.317)\end{array}$ & $\begin{array}{l}-0.955^{\star * *} \\
(0.284)\end{array}$ & $\begin{array}{l}-0.446^{*} \\
(0.224)\end{array}$ & $\begin{array}{l}-0.619^{* *} \\
(0.252)\end{array}$ \\
\hline Per capita income & $\begin{array}{l}0.000 \\
(0.000)\end{array}$ & $\begin{array}{l}0.000 \\
(0.000)\end{array}$ & $\begin{array}{l}0.001^{\star * *} \\
(0.000)\end{array}$ & $\begin{array}{l}0.001^{* * *} \\
(0.000)\end{array}$ & $\begin{array}{l}0.001^{* * *} \\
(0.000)\end{array}$ & $\begin{array}{l}0.001^{* *} \\
(0.000)\end{array}$ \\
\hline Inflation & $\begin{array}{l}0.004 \\
(0.004)\end{array}$ & $\begin{array}{l}0.003 \\
(0.004)\end{array}$ & $\begin{array}{l}-0.002 \\
(0.008)\end{array}$ & $\begin{array}{l}-0.002 \\
(0.006)\end{array}$ & $\begin{array}{l}-0.003^{* * *} \\
(0.001)\end{array}$ & $\begin{array}{l}-0.003 \\
(0.002)\end{array}$ \\
\hline Debt servicing & $\begin{array}{l}-0.155^{\star *} \\
(0.075)\end{array}$ & $\begin{array}{l}-0.082 \\
(0.089)\end{array}$ & $\begin{array}{l}-0.094^{\star * *} \\
(0.027)\end{array}$ & $\begin{array}{l}-0.095^{\star *} \\
(0.039)\end{array}$ & $\begin{array}{l}-0.101^{* *} \\
(0.047)\end{array}$ & $\begin{array}{l}-0.104^{* *} \\
(0.050)\end{array}$ \\
\hline Quality of government & $\begin{array}{l}-1.387 \\
(2.881)\end{array}$ & $\begin{array}{l}0.175 \\
(2.643)\end{array}$ & $\begin{array}{l}0.311 \\
(1.333)\end{array}$ & $\begin{array}{l}1.029 \\
(1.136)\end{array}$ & $\begin{array}{l}0.483 \\
(1.267)\end{array}$ & $\begin{array}{l}1.461 \\
(1.541)\end{array}$ \\
\hline Constant & $\begin{array}{l}3.667^{*} \\
(1.876) \\
\end{array}$ & $\begin{array}{l}5.813^{* *} \\
(2.334) \\
\end{array}$ & $\begin{array}{l}3.644^{* * *} \\
(1.140) \\
\end{array}$ & $\begin{array}{l}3.460^{*} \\
(1.871) \\
\end{array}$ & $\begin{array}{l}3.131^{* *} \\
(1.377) \\
\end{array}$ & $\begin{array}{l}- \\
- \\
\end{array}$ \\
\hline Observations & 261 & 250 & 261 & 250 & 261 & 250 \\
\hline R-squared & 0.458 & 0.470 & 0.379 & 0.445 & 0.297 & 0.301 \\
\hline Country FE & NO & NO & NO & NO & YES & YES \\
\hline Number of countries & 70 & 68 & 70 & 68 & 70 & 68 \\
\hline Cragg-Donald F-stat & & 27.27 & & 21.42 & & 17.41 \\
\hline Kleibergen-Paap F-stat & & 16.35 & & 19.55 & & 15.54 \\
\hline Kleibergen-Paap LM-stat & & 9.102 & & 11.93 & & 9.442 \\
\hline $\begin{array}{l}\text { Kleibergen-Paap LM-stat ( } p \text { - } \\
\text { value) }\end{array}$ & & 0.0106 & & 0.002 & & 0.00890 \\
\hline Hansen test ( $p$-value) & & 0.724 & & 0.603 & & 0.917 \\
\hline
\end{tabular}

Source: Authors' calculation based on panel dataset.

Now we would like to turn our attention on the role of inequality in social protection spending as this is an indication of society's attitudes towards aversion to current inequality. The estimated coefficient on income inequality in the form of the Gini coefficient is negative but not statistically significant, without any other institutional covariates (Table 6). This suggests that social sector spending as a proportion of national income is higher in more egalitarian societies. Societies with a greater inequality tolerance may become immune to the suffering of the poor, and systematically spend less in alleviating poverty and redressing inequality, as pointed out in Gassman et al. (2016). This may be especially so when the gap in income (and wealth) of the (super-) rich widens in relation to both the poor and middle classes. The size of the coefficient on fiscal capacity is larger than before, suggesting that fiscal capacity plays an important role in determining the extent of social protection in inequality-averse societies. The other covariates retain their earlier sign and 
significance. We also employed the Palma ratio in place of the Gini coefficient; the results are qualitatively similar and are therefore not reported. ${ }^{10}$

We also do not report the combined effects of institutional and inequality measures here. If polity and inequality are simultaneously included, inequality remains insignificant but polity continues to be positively significant except with FE estimators, which can be partially discounted due to the within-country time invariance of polity scores. This underscores the importance of the political process in the shape of greater democracy in determining social sector expenditure. If the quality of governance and inequality are simultaneously included, the coefficient on inequality is negative and significant, whereas the governance variable is insignificant. Governance matters less than society's inequality aversion in determining the size of social protection expenditure.

Table 6: Role of fiscal capacity and inequality (Gini) in social protection expenditure

\begin{tabular}{|c|c|c|c|c|c|c|}
\hline Explanatory variable & $\begin{array}{l}\text { OLS } \\
(1)\end{array}$ & $\begin{array}{l}\text { OLS IV } \\
(2)\end{array}$ & $\begin{array}{l}\mathrm{RE} \\
(3) \\
\end{array}$ & $\begin{array}{l}\text { RE IV } \\
(4)\end{array}$ & $\begin{array}{l}\text { FE } \\
(5) \\
\end{array}$ & $\begin{array}{l}\text { FE IV } \\
(6)\end{array}$ \\
\hline Fiscal capacity & $\begin{array}{l}0.275^{\star \star \star} \\
(0.051)\end{array}$ & $\begin{array}{l}0.265^{\star *} \\
(0.112)\end{array}$ & $\begin{array}{l}0.161^{* * *} \\
(0.031)\end{array}$ & $\begin{array}{l}0.198^{\star *} \\
(0.079)\end{array}$ & $\begin{array}{l}0.113^{\star * *} \\
(0.042)\end{array}$ & $\begin{array}{l}0.194^{\star *} \\
(0.074)\end{array}$ \\
\hline Population growth & $\begin{array}{l}-1.194^{\star * *} \\
(0.325)\end{array}$ & $\begin{array}{l}-1.204^{\star * *} \\
(0.339)\end{array}$ & $\begin{array}{l}-1.064^{* * *} \\
(0.212)\end{array}$ & $\begin{array}{l}-1.047^{\star * *} \\
(0.206)\end{array}$ & $\begin{array}{l}-0.838^{* * *} \\
(0.211)\end{array}$ & $\begin{array}{l}-0.878^{\star * *} \\
(0.228)\end{array}$ \\
\hline Per capita income & $\begin{array}{l}0.000 \\
(0.000)\end{array}$ & $\begin{array}{l}0.000 \\
(0.000)\end{array}$ & $\begin{array}{l}0.001^{* * *} \\
(0.000)\end{array}$ & $\begin{array}{l}0.001^{* * *} \\
(0.000)\end{array}$ & $\begin{array}{l}0.001^{\star *} \\
(0.000)\end{array}$ & $\begin{array}{l}0.001^{* *} \\
(0.000)\end{array}$ \\
\hline Inflation & $\begin{array}{l}0.026^{\star \star} \\
(0.013)\end{array}$ & $\begin{array}{l}0.026^{\star \star} \\
(0.013)\end{array}$ & $\begin{array}{l}0.003 \\
(0.011)\end{array}$ & $\begin{array}{l}0.005 \\
(0.012)\end{array}$ & $\begin{array}{l}-0.002 \\
(0.007)\end{array}$ & $\begin{array}{l}0.002 \\
(0.011)\end{array}$ \\
\hline Debt servicing & $\begin{array}{l}-0.105 \\
(0.078)\end{array}$ & $\begin{array}{l}-0.083 \\
(0.085)\end{array}$ & $\begin{array}{l}-0.096^{\text {*** }} \\
(0.035)\end{array}$ & $\begin{array}{l}-0.114^{* *} \\
(0.050)\end{array}$ & $\begin{array}{l}-0.142^{* *} \\
(0.064)\end{array}$ & $\begin{array}{l}-0.154^{* *} \\
(0.067)\end{array}$ \\
\hline Income inequality (Gini) & $\begin{array}{l}-0.014 \\
(0.038)\end{array}$ & $\begin{array}{l}-0.017 \\
(0.039)\end{array}$ & $\begin{array}{l}-0.041^{*} \\
(0.025)\end{array}$ & $\begin{array}{l}-0.038 \\
(0.026)\end{array}$ & $\begin{array}{l}-0.043 \\
(0.030)\end{array}$ & $\begin{array}{l}-0.030 \\
(0.034)\end{array}$ \\
\hline Constant & $\begin{array}{l}1.679 \\
(1.896)\end{array}$ & $\begin{array}{l}1.934 \\
(2.823) \\
\end{array}$ & $\begin{array}{l}4.867^{\star \star *} \\
(1.612)\end{array}$ & $\begin{array}{l}4.060 \\
(2.586)\end{array}$ & $\begin{array}{l}5.572^{\star \star *} \\
(2.077)\end{array}$ & $\begin{array}{l}- \\
-\end{array}$ \\
\hline Observations & 249 & 244 & 249 & 244 & 249 & 222 \\
\hline R-squared & 0.549 & 0.551 & 0.509 & 0.526 & 0.387 & 0.361 \\
\hline Country FE & NO & NO & NO & NO & YES & YES \\
\hline Number of countries & 90 & 89 & 90 & 89 & 90 & 67 \\
\hline Cragg-Donald F-stat & & 15.46 & & 21.43 & & 17.23 \\
\hline Kleibergen-Paap F-stat & & 11.98 & & 19.21 & & 12.27 \\
\hline Kleibergen-Paap LM-stat & & 15.79 & & 13.82 & & 9.048 \\
\hline $\begin{array}{l}\text { Kleibergen-Paap LM-stat ( } p \text { - } \\
\text { value) }\end{array}$ & & 0.000373 & & 0.001 & & 0.0108 \\
\hline Hansen test (p-value) & & 0.829 & & 0.881 & & 0.990 \\
\hline
\end{tabular}

Robust standard errors in parentheses ${ }^{* * *} p<0.01,{ }^{* *} p<0.05,{ }^{*} p<0.1$

Source: Authors' calculation based on panel dataset.

The regression results after incorporation of conflict in the form of civil war or inter-state war into the analysis, but without other institutional and inequality variables is presented in Table 7 . The conflict variable is a dummy variable, which takes on the value of 1 when there is conflict, regardless of intensity. The coefficient on conflict is positive but insignificant, suggesting that conflict does exert some upward pressure on the amount of social sector spending. The other covariates are largely unchanged. As an extension of our current estimate we also examine the combined effect of conflict and institutions. In this regard, when we include both polity and conflict, polity retains its significance but conflict does not. When the quality of governance and conflict are included together, neither is significant.

\footnotetext{
${ }^{10}$ A full set of regression results are available from the authors upon request.
} 


\subsection{Robustness analysis}

When we truncate our sample to include only low- and middle-income countries, thus excluding the more affluent countries in the sample, the contributions of inflation and democracy and the quality of government become marginally more salient. Excluding more democratic countries, those with a polity score of 6 and above, does not really alter our results but weakens them. Per capita income is significant in most cases. Inflation is positive and significant in only one case . The burden of external debt servicing is negative and significant in most cases. Most importantly, democracy contributes positively and significantly in most cases, and conflict continues to retain a positive and insignificant coefficient. These findings suggest that our earlier results are robust to alternative specifications and sample sizes.

Table 7: Role of fiscal capacity and conflict in social protection spending

\begin{tabular}{|c|c|c|c|c|c|c|}
\hline Explanatory variables & $\begin{array}{l}\text { OLS } \\
(1)\end{array}$ & $\begin{array}{l}\text { OLS IV } \\
(2)\end{array}$ & $\begin{array}{l}\mathrm{RE} \\
(3)\end{array}$ & $\begin{array}{l}\text { RE IV } \\
(4)\end{array}$ & $\begin{array}{l}\text { FE } \\
(5)\end{array}$ & $\begin{array}{l}\text { FE IV } \\
(6)\end{array}$ \\
\hline Fiscal capacity & $\begin{array}{l}0.198^{* * *} \\
(0.042)\end{array}$ & $\begin{array}{l}0.189^{\star *} \\
(0.090)\end{array}$ & $\begin{array}{l}0.109^{\star \star *} \\
(0.027)\end{array}$ & $\begin{array}{l}0.165^{\star *} \\
(0.066)\end{array}$ & $\begin{array}{l}0.076^{\star \star \star} \\
(0.025)\end{array}$ & $\begin{array}{l}0.123^{\star *} \\
(0.058)\end{array}$ \\
\hline Population growth & $\begin{array}{l}-1.101^{\star * *} \\
(0.323)\end{array}$ & $\begin{array}{l}-1.299^{* * *} \\
(0.322)\end{array}$ & $\begin{array}{l}-0.605^{\star * *} \\
(0.208)\end{array}$ & $\begin{array}{l}-0.792^{* * *} \\
(0.184)\end{array}$ & $\begin{array}{l}-0.413^{\star *} \\
(0.167)\end{array}$ & $\begin{array}{l}-0.520^{* * *} \\
(0.180)\end{array}$ \\
\hline Per capita income & $\begin{array}{l}0.000 \\
(0.000)\end{array}$ & $\begin{array}{l}0.000 \\
(0.000)\end{array}$ & $\begin{array}{l}0.001^{\star \star \star} \\
(0.000)\end{array}$ & $\begin{array}{l}0.001^{\star * \star} \\
(0.000)\end{array}$ & $\begin{array}{l}0.001^{\star \star \star} \\
(0.000)\end{array}$ & $\begin{array}{l}0.001^{\star \star \star} \\
(0.000)\end{array}$ \\
\hline Inflation & $\begin{array}{l}0.005 \\
(0.005)\end{array}$ & $\begin{array}{l}0.005 \\
(0.005)\end{array}$ & $\begin{array}{l}-0.002 \\
(0.008)\end{array}$ & $\begin{array}{l}-0.001 \\
(0.007)\end{array}$ & $\begin{array}{l}-0.003^{\star * *} \\
(0.001)\end{array}$ & $\begin{array}{l}-0.002 \\
(0.002)\end{array}$ \\
\hline Debt servicing & $\begin{array}{l}-0.065 \\
(0.064)\end{array}$ & $\begin{array}{l}-0.048 \\
(0.067)\end{array}$ & $\begin{array}{l}-0.091^{* *} \\
(0.040)\end{array}$ & $\begin{array}{l}-0.081^{\star * *} \\
(0.030)\end{array}$ & $\begin{array}{l}-0.102^{\star *} \\
(0.042)\end{array}$ & $\begin{array}{l}-0.098^{* *} \\
(0.045)\end{array}$ \\
\hline Conflict & $\begin{array}{l}0.456 \\
(0.532)\end{array}$ & $\begin{array}{l}0.410 \\
(0.559)\end{array}$ & $\begin{array}{l}0.205 \\
(0.410)\end{array}$ & $\begin{array}{l}0.252 \\
(0.402)\end{array}$ & $\begin{array}{l}0.093 \\
(0.387)\end{array}$ & $\begin{array}{l}0.112 \\
(0.397)\end{array}$ \\
\hline Constant & $\begin{array}{l}2.346^{\star *} \\
(1.058) \\
\end{array}$ & $\begin{array}{l}2.755 \\
(2.112) \\
\end{array}$ & $\begin{array}{l}3.193^{* * *} \\
(0.816) \\
\end{array}$ & $\begin{array}{l}2.258 \\
(1.698) \\
\end{array}$ & $\begin{array}{l}2.904^{* \star *} \\
(0.899)\end{array}$ & $\begin{array}{l}- \\
- \\
\end{array}$ \\
\hline Observations & 351 & 336 & 351 & 336 & 351 & 335 \\
\hline R-squared & 0.411 & 0.464 & 0.347 & 0.430 & 0.289 & 0.293 \\
\hline Country FE & NO & NO & NO & NO & YES & YES \\
\hline Number of countries & 97 & 94 & 97 & 94 & 97 & 93 \\
\hline Cragg-Donald F-stat & & 32.78 & & 35.76 & & 29.48 \\
\hline Kleibergen-Paap F-stat & & 19.64 & & 32.34 & & 20.65 \\
\hline Kleibergen-Paap LM-stat & & 14.65 & & 20.07 & & 14.40 \\
\hline $\begin{array}{l}\text { Kleibergen-Paap LM-stat(p- } \\
\text { value) }\end{array}$ & & 0.000657 & & 0.000 & & 0.000745 \\
\hline Hansen test ( $p$-value) & & 0.369 & & 0.111 & & 0.111 \\
\hline
\end{tabular}

Source: Authors' calculation based on panel dataset.

\section{Conclusions}

We have attempted to analyse the determinants of social protection, which are chiefly fiscal capacity, per capita income, the degree of democracy, and the quality of government, but also inequality and conflict in a cross-section of developing countries covering two decades between 1990 and 2010. We employ other covariates such as debt servicing and inflation, control for endogeneity and carry out a host of robustness checks.

Be that as it may, our results suggest that the most robust explanatory variable for social protection expenditure variable is fiscal capacity measured as total revenues (taxes, royalties, aid, and other proceeds accruing to the state) as share of GDP, which is invariably significant with a positive sign. The magnitude of the coefficient on fiscal capacity varies from 0.10 to 0.19 , which indicates that a 1 per cent increase in fiscal capacity (as a percentage share of GDP) will increase social protection 
spending (as percentage share of GDP) by at least 0.10 percentage points and 0.19 points as maximum. After that, the burden of external debt servicing almost always (in the panel data estimations) exerts a negative and significant impact on social sector spending. Higher per capita income also has a positive and significant impact on social sector expenditure in nearly all of our panel data type estimations. Taken together, these findings reinforce our intuition that richer countries with a greater fiscal capacity can afford more social sector expenditure. Inflation does not significantly retard social protection expenditure in most cases, although its sign is sometimes positive, indicating the positive impact of seigniorage revenues, but often negative pointing to contractionary fiscal policies following inflation. Population growth invariably has a negative and significant impact on social expenditure as a proportion of national income.

Fiscal capacity is necessary, but not sufficient, in determining the extent of social protection expenditure. As hypothesized, greater democracy promotes more social protection expenditure, as it leads to the greater realization of median voter preferences for more social protection. More democratic nations, on an average, care more about the poor or the middle classes, who are the chief beneficiaries of certain types of social sector expenditure in developing countries. The rising tide of social sector spending in developing countries over the last two decades has also been accompanied by a movement from autocracy to (imperfect) democracy in the developing world. Interestingly, good governance, despite its positive impact on social sector spending, is mainly insignificant, suggesting that as far as the determinants of expenditure are concerned, a democratic polity rather than good governance is more important. This leaves an open question as to the quality of social provision, as well as specific societal preferences of the type of social sector spending which may be more closely related to good governance.

More importantly, our paper employs income inequality as a determinant of social sector expenditure. We utilize Gini coefficients of inequality and the Palma ratio of the shares of the rich relative to the poor. The more egalitarian the society, the greater the degree of social protection, suggesting that the increased separation of the poor and middle classes from the rich and superrich is not propitious for these types of public spending. The extent of social protection in inequality-averse societies is constrained by fiscal capacity. The presence of conflict in the form of either civil war or war can exert upward pressures to bring about social sector expenditure, but this effect is not statistically significant.

As far as the policy implications are concerned, efforts to promote greater social sector spending should aim at debt relief and greater fiscal capacity. On the institutional side, greater democracy, especially greater democracy in conjunction with fiscal capacity, promotes this type of spending.

Besides alleviating absolute and grinding poverty, social protection can help to redress the harmful effects of inequality, particularly inequality of opportunity, which is arguably the great scourge of our time. As indicated in our literature review, inequality is also growth retarding during recent times, and social sector expenditures do not appear to crowd out growth prospects. Enhanced fiscal capacity is key to the goal of greater social sector spending, and in this connection it is crucial to be able to increase taxation of the ultra-rich and the multinational corporate sector, who are both adroitly and through political clout avoiding their fair share of tax. Otherwise, all efforts in the direction of greater justice with increased prosperity for the majority will, like faith without charity, come to nothing. 


\section{References}

Acemoglu, D., and J.A. Robinson (2009). Economic Origins of Dictatorship and Democracy. New York: Cambridge University Press.

Alderman, H., and R. Yemtsov (2012). 'How Can Safety-nets Contribute to Economic Growth?' Policy Research Working Paper 6437. Washington, DC: World Bank.

Alderman, H., and R. Yemtsov (2013). 'Productive Role of Social Protection'. Background Paper for the World Bank 2012-22, Social Protection and Labor Strategy, World Bank, Washington.

Alesina, A., and D. Rodrik (1994). 'Distributive Policies and Economic Growth'. Quarterly Journal of Economics, 109(2): 465-90.

Barrientos, A. (2013). 'Social Transfers and Growth: What Do We Know? What Do We Need to Find Out?' World Development, 40(1): 11-20.

Bénabou, R., and J. Tirole (2013). 'Bonus Culture: Competitive Pay, Screening and Multitasking'. NBER Working Paper 18936. Cambridge, MA: National Bureau of Economic Research.

Besley, T., and T. Persson (2010). 'State Capacity, Conflict and Development'. Econometrica, 78(1): $1-34$.

Chiripanhura, B., and Niño-Zarazúa, M. (2015). 'Aid, Political Business Cycles and Growth in Africa'. Journal of International Development, 27: 1387-421. doi: 10.1002/jid.3188.

Cobham, A., and A. Sumner (2013). 'Is It All about the Tails? The Palma Measure of Income Inequality’. CGD Working Paper 343. Washington, DC: Center for Global Development.

Credit Suisse (2010). 'Global Wealth Report'. Available at: https://www.creditsuisse.com/uk/en/about-us/research/research-institute/global-wealth-report.html (accessed 1 December 2016).

Dabla-Norris, E., K. Kochkar, N. Suphaphiphat, F. Ricka, and E. Tsounta (2015). 'Causes and Consequences of Income Inequality: A Global Perspective'. IMF Staff Discussion Note. Washington, DC: International Monetary Fund.

Dahlberg, S., S. Holmberg, B. Rothstein, and F. Hartmann (2013). 'The Quality of Government Basic Dataset Made from the Quality of Government Dataset', version of 15 May. University of Gothenburg: Quality of Government Institute.

Dincecco, M., and G. Katz (2016). 'State Capacity and Long-run Economic Performance'. Economic Journal, 126(590): 189-218.

Dincecco, M., and M. Prado (2012). 'Warfare, Fiscal Capacity, and Performance'. Journal of Economic Growth, 17(3): 171-203.

Dodlova, M., and A. Giolbas (2016). 'Regime Type, Inequality and Redistributive Transfers in Developing Countries'. Paper presented at the UNU-WIDER Symposium on Social Protection, Mexico City, 8-10 February.

Dodlova, M., and J. Lay (2016). 'Political Regimes and Pro-poor Transfers in Developing Countries'. Paper presented at the UNU-WIDER Symposium on Social Protection, Mexico City, 8-10 February.

Downs, A. (1957). An Economic Theory of Democracy. New York: Harper \& Row.

Easterly, W. (2007). 'Inequality Does Cause Underdevelopment: Insights from a New Instrument'. Journal of Development Economics, 84(2): 755-76. 
Egger, P., D. Radulescu, and N. Strecker (2016). 'On the Spread of Social Protection Systems'. UNU-WIDER Working Paper 2016/99. Helsinki: UNU-WIDER.

Gassman, F., P. Mohnen, and V. Vinci (2016). 'Institutional Factors and People's Preferences in Social Protection'. UNU-MERIT, Working Paper 2016-003. Maastricht: UNU-MERIT.

Gebregziabher, F., and M. Niño-Zarazúa (2014). 'Social Spending and Aggregate Welfare in Developing and Transition Economies'. UNU-WIDER Working Paper 2014/082. Helsinki: UNU-WIDER.

Hahn, J., J. Hausman, and G. Kuersteiner (2004). 'Estimation with Weak Instruments: Accuracy of Higher-order Bias and MSE Approximations'. Econometrics Journal, 7(1): 272-306.

Huber, E., T. Mustillo, and J.D. Stephens (2004). 'Determinants of Social Spending in Latin America'. Paper prepared for the Society for the Advancement of Socio-Economics Meeting in Washington, 8-11 July 2004.

ILO (2014a). World Social Protection Report 2014/15: Building Economic Recovery, Inclusive Development and Social Justice. Geneva: International Labour Organization.

ILO (2014b). World of Work Report: Developing with Jobs, 2nd edn. Geneva: International Labour Organization.

IMF (n.d.) IMF World Economic Outlook database. International Monetary Fund. Available at: http://www.imf.org/external/pubs/ft/weo/2015/01/weodata/download.aspx (accessed 17 January 2016).

Jorda, V., and M. Niño-Zarazúa (2016). 'Global Inequality: How Large is the Effect of Top Incomes?’ UNU-WIDER Working Paper 2016/94. Helsinki: UNU-WIDER.

Kaldor, N. (1957). 'A Model of Economic Growth'. Economic Journal, 67(268): 591-624.

Kuznets, S. (1955). 'Economic Growth and Income Inequality'. American Economic Review, 45(1): $1-38$.

Lakner, C., and B. Milanovic (2015). 'Global Income Distribution: From the Fall of the Berlin Wall to the Great Recession'. World Bank Economic Review, doi: 10.1093/wber/lhv039.

Mayoral, F.M., and M.K. Nabernegg (n.d.). 'Determinants of Social Spending in Latin America: A Dynamic Panel Data Error-correction Model Analysis'. FLACSO, Ecuador. Available at: http://www.icpublicpolicy.org/conference/file/reponse/1431373816.pdf (accessed 2 March 2017).

Meltzer, A.H., and S.F. Richard (1981). 'A Rational Theory of Government'. Journal of Political Economy, 89(5): 914-27.

Murshed, S.M. (2010). Explaining Civil War: A Rational Choice Approach. Cheltenham: Edward Elgar.

Okun, A. (1975). Equality and Efficiency: The Big Trade-Off. Washington, DC: Brookings Press.

Orhangazi, O. (2008). 'Financialization and Capital Accumulation in the Nonfinancial Corporate Sector: A Theoretical and Empirical Investigation on the US Economy, 1973-2003'. Cambridge Journal of Economics, 32(6): 863-86.

Ostry, J.D., A. Berg, and C. Tsangarides (2014). 'Redistribution, Inequality and Growth'. IMF Staff Discussion Note. Washington, DC: International Monetary Fund.

Oxfam (2016). 'Wealth: Having It All and Wanting More'. Available at: https://www.oxfam.org/sites/www.oxfam.org/files/file_attachments/ib-wealth-having-allwanting-more-190115-en.pdf (accessed 23 January 2016). 
Palma, J.G. (2011). 'Homogeneous Middles vs. Heterogeneous Tails, and the End of the "Inverted-U": It's All About the Share of the Rich'. Development and Change, 42(1): 87-153.

Papadia, A. (2016). 'Fiscal Capacity, Tax Composition and the (in)Stability of Government Revenues in the Interwar Period'. London School of Economics, Department of Economic History (mimeo).

Piketty, T. (2014). Capital in the Twenty-first Century. Cambridge, MA: Harvard University Press.

Rodrik, D. (1998). 'Why Do More Open Economies Have Bigger Governments?' Journal of Political Economy, 106(5): 997-1032.

Rodrik, D. (1999). 'Where Did All the Growth Go? External Shocks, Social Conflict, and Growth Collapses'. Journal of Economic Growth, 4(4): 385-412.

Roemer, J.E. (1998). Equality of Opportunity. Cambridge MA: Harvard University Press.

Rogers, M.Z., and N. Weller (2013). 'Income Taxation and the Validity of State Capacity Indicators'. Journal of Public Policy, 34(3): 183-206.

Ross, M.L. (2012). The Oil Curse: How Petroleum Wealth Shapes the Development of Nations. Princeton, NJ: Princeton University Press.

Shonchoy, A.S. (2010). 'Determinants of Government Consumption Expenditure in Developing Countries: A Panel Data Analysis’. IDE Discussion Paper 266.

Snyder, J.M., and I. Yackovlev (2000). 'Political and Economic Determinants of Government Spending on Social Protection Programmes'. manuscript, MIT.

Solt, F. (2014). 'The Standardized World Income Inequality Database'. Working Paper, SWIID Version 5.0, October 2014.

Solt, F. (2016). 'The Standardized World Income Inequality Database'. Social Science Quarterly, 97(5): 1267-81.

Stiglitz, J. (2012). The Price of Inequality: How Today's Divided Society Endangers Our Future. New York: Norton.

Stiglitz, J., and A. Weiss (1981). 'Credit Rationing in Markets with Imperfect Information'. American Economic Review, 71(3): 393-410.

Tavares, J., and R. Wacziarg (2001). 'How Democracy Affects Growth'. European Economic Review, 45(8): 1341-78. 


\begin{tabular}{|c|c|}
\hline Name and definition & Source \\
\hline $\begin{array}{l}\text { Social protection expenditure is the sum of annual expenditure } \\
\text { (including benefit expenditure and administration costs) of all existing } \\
\text { public social security/social protection schemes or programmes in the } \\
\text { country. The scope of the indicators corresponds to the scope of the } \\
\text { Social Security (Minimum Standards) Convention, } 1952 \text { (No.102), } \\
\text { which established nine classes of benefits: medical care, sickness } \\
\text { benefit, unemployment benefit, old-age benefit, employment injury } \\
\text { benefit, family benefit, maternity benefit, invalidity benefit and } \\
\text { survivors' benefit, plus other income support and assistance } \\
\text { programmes, including conditional cash transfers, available to the } \\
\text { poor and not included under the above classes. It is inclusive of } \\
\text { public health expenditure as well. It is expressed as a share of GDP. } \\
\text { Nominators and denominators are expressed in national currency } \\
\text { units, current prices. }\end{array}$ & $\begin{array}{l}\text { ILO, World Social Protection Report } \\
2014 / 15\end{array}$ \\
\hline $\begin{array}{l}\text { Fiscal capacity is measured by revenue:GDP ratio. Revenue consists } \\
\text { of taxes, social contributions, grants receivable, and other revenue. } \\
\text { Revenue increases government's net worth, which is the difference } \\
\text { between its assets and liabilities. }\end{array}$ & $\begin{array}{l}\text { IMF World Economic Outlook database: } \\
\text { http://www.imf.org/external/pubs/ft/weo/ } \\
\text { 2015/01/weodata/download.aspx } \\
\text { (accessed } 17 \text { January 2016) }\end{array}$ \\
\hline $\begin{array}{l}\text { Polity } 2 \text { gives the combined autocracy and democracy score of } \\
\text { between }-10 \text { and }+10 \text {, with }+10 \text { being the best (democracy) and }-10 \\
\text { the worst (autocracy). }\end{array}$ & $\begin{array}{l}\text { Polity IV dataset: } \\
\text { http://www.systemicpeace.org/inscrdata } \\
\text {.html (accessed } 1 \text { December 2014) }\end{array}$ \\
\hline $\begin{array}{l}\text { Quality of government is an aggregation of mean value of the three } \\
\text { variables; corruption, law and order, and bureaucracy quality scaled } \\
\text { between } 0 \text { and } 1 . \text { Higher values indicate higher quality of } \\
\text { government. These three variables are originally generated by the } \\
\text { ICRG dataset. The aggregate variable quality of government is } \\
\text { constructed by the Quality of Government Standard Dataset } 2016 \text {, } \\
\text { Quality of Government Institute, University of Gothenburg, Sweden. }\end{array}$ & $\begin{array}{l}\text { Dahlberg, S., S. Holmberg, B. } \\
\text { Rothstein, A. Khomenko, and R. } \\
\text { Svensson (2016). The Quality of } \\
\text { Government Basic Dataset, version } \\
\text { Jan16. University of Gothenburg: } \\
\text { Quality of Government Institute, } \\
\text { http://www.qog.pol.gu.se, } \\
\text { doi:10.18157/QoGBasJan16 }\end{array}$ \\
\hline $\begin{array}{l}\text { The conflict variable is a combination of two broad types of conflict } \\
\text { defined by the UCDP dataset namely; inter-state armed conflict and } \\
\text { internal conflict (internal and internationalized internal armed conflict). } \\
\text { It considers both low-intensity or minor armed conflict and high- } \\
\text { intensity armed conflict (or war). According to the UCDP dataset, low- } \\
\text { intensity conflict is defined as having a minimum threshold of } 25 \\
\text { battle deaths per year, while high-intensity conflict (or war) involves a } \\
1,000 \text { or more battle deaths per year. It is a dummy variable taking } \\
\text { the value of } 1 \text { if there is armed conflict and } 0 \text { otherwise. }\end{array}$ & $\begin{array}{l}\text { Melander, E., T. Pettersson, and L. } \\
\text { Themnér (2016). 'Organized Violence, } \\
\text { 1989-2015'. Journal of Peace } \\
\text { Research, 53(5). } \\
\text { Gleditsch, N.P., P. Wallensteen, M. } \\
\text { Eriksson, M. Sollenberg, and H. Strand } \\
\text { (2002). 'Armed Conflict 1946-2001: A } \\
\text { New Dataset'. Journal of Peace } \\
\text { Research 39(5). Available at: } \\
\text { http://ucdp.uu.se/downloads/ (accessed } \\
26 \text { December 2016). }\end{array}$ \\
\hline $\begin{array}{l}\text { The Gini coefficient of income inequality ranges between } 0 \text { and 100, } \\
\text { with larger values corresponding to more unequal income } \\
\text { distributions. }\end{array}$ & \multirow{8}{*}{$\begin{array}{l}\text { World Development Indicators (WDI), } \\
\text { World Bank }\end{array}$} \\
\hline $\begin{array}{l}\text { The Palma ratio is a measure of inequality. It is the ratio of the richest } \\
10 \% \text { of the population's share of GNI divided by the poorest } 40 \% \text { 's } \\
\text { share. Data on this variable is constructed with the help of available } \\
\text { data on income distribution at the World Development Indicators } \\
\text { website of the World Bank. }\end{array}$ & \\
\hline $\begin{array}{l}\text { Debt service: total debt service is the sum of principal repayments } \\
\text { and interest actually paid in currency, goods, or services on long-term } \\
\text { debt, interest paid on short-term debt, and repayments (repurchases } \\
\text { and charges) to the IMF. It is a percentage of GNI. }\end{array}$ & \\
\hline Population growth & \\
\hline Per capita income/GDP (in constant price of year 2005) & \\
\hline Rate of inflation & \\
\hline Share of agriculture in GDP & \\
\hline Share of mineral resource rents in GDP & \\
\hline
\end{tabular}


Annex Table A2: List of countries

\begin{tabular}{|c|c|c|}
\hline Name of country & Name of country & Name of country \\
\hline Afghanistan & Guyana & Tajikistan \\
\hline Albania & Honduras & Tanzania \\
\hline Algeria & India & Thailand \\
\hline Armenia & Indonesia & Togo \\
\hline Azerbaijan & Iran, Islamic Rep. & Tonga \\
\hline Bangladesh & Jamaica & Tunisia \\
\hline Belarus & Jordan & Turkey \\
\hline Belize & Kenya & Uganda \\
\hline Benin & Kyrgyz Republic & Ukraine \\
\hline Bhutan & Lao PDR & Uzbekistan \\
\hline Bolivia & Lebanon & Vanuatu \\
\hline Bosnia and Herzegovina & Liberia & Viet Nam \\
\hline Botswana & Madagascar & Yemen, Rep. \\
\hline Brazil & Malaysia & Zambia \\
\hline Bulgaria & Maldives & Zimbabwe \\
\hline Burkina Faso & Maldives & \\
\hline Burundi & Mauritania & \\
\hline Cambodia & Mauritius & \\
\hline Cameroon & Mexico & \\
\hline Central African Republic & Mongolia & \\
\hline China & Morocco & \\
\hline Colombia & Mozambique & \\
\hline Congo, Dem. Rep. & Nepal & \\
\hline Congo, Rep. & Nicaragua & \\
\hline Costa Rica & Niger & \\
\hline Cote d'Ivoire & Pakistan & \\
\hline Dominica & Panama & \\
\hline Dominican Republic & Papua New Guinea & \\
\hline Ecuador & Paraguay & \\
\hline Egypt, Arab Rep. & Peru & \\
\hline El Salvador & Philippines & \\
\hline Eritrea & Romania & \\
\hline Ethiopia & Rwanda & \\
\hline Fiji & Senegal & \\
\hline Gambia, The & Sierra Leone & \\
\hline Georgia & Solomon Islands & \\
\hline Ghana & South Africa & \\
\hline Grenada & Sri Lanka & \\
\hline Guatemala & Sudan & \\
\hline Guinea & Swaziland & \\
\hline Guinea-Bissau & Syrian Arab Republic & \\
\hline
\end{tabular}

